\title{
Boxing, danger and masculinity in Mexico city
}

\begin{abstract}
The inherent risk in practicing sports and the capacity to withstand pain are fundamental components of the imaginary of masculinity and contribute to create a culture of gender in this field. Nowhere is this more obvious than in boxing. Although there is a health culture in boxing, participants interpret risk as a given aspect of the sport and as a function of the value of virility and tend to deny or minimize the consequences their practice may have on their physical integrity. Research in Mexico shows the role of boxing in constructing male identity and defending a field notwithstanding the dangerousness of the practice.
\end{abstract}

Keywords: gender, masculinity, boxing, body, injuries
Volume 3 Issue I - 2019

\section{Hortensia Moreno}

Centro de Investigaciones y Estudios de Género, Universidad Nacional Autónoma de México, USA

\begin{abstract}
Correspondence: Hortensia Moreno, Centro de Investigaciones y Estudios de Género, Universidad Nacional Autónoma de México,Torre II de Humanidades, $7^{\circ}$ piso, Ciudad Universitaria, 04510, Ciudad de México, México, USA, Tel 52(55)5623-0022, Email hortensia_moreno@cieg.unam.mx
\end{abstract}

Received: June 06, 2018 | Published: Januvary 03, 2019

\section{Introduction}

Some of the scholars studying masculinity have attended the problem of the risk factors that appear as main features of the gender identity that men have to fulfill in order to be acceptable for the imaginary order in some cultures, as long as a masculine identity "is not something you have but something that is done". ${ }^{1}$ For Barnes, ${ }^{2}$ Brown and Tamborski " "The circumstances that require men to prove their manhood are numerous and varied, and this fact renders manhood a volatile social status that must be constantly upheld with demonstrations of toughness and bravery." Most of the research proves that violence can become a way of asserting masculinity, and that male aggression remains the 'dark side' of masculine role performance in all 'modern' societies. ${ }^{4}$ Nevertheless, as Carrigan \& Connell ${ }^{4}$ have discussed, not all men act hegemonic masculinity; but most of them are complicit with it. "In recent years violence has been identified as a worldwide health concern, and in understanding violence there is an increasing emphasis on the social and cultural context". ${ }^{5}$ The cultural context determines some masculinizing practices being damaging for the body; some practices are authorized by discourses and social norms influencing violent behavior: Within accounts of masculinity as being 'accomplished' through an involvement in crime, men are seen as 'doing' their gender (masculinity) by engaging in diverse crimes such as burglary, rape, the sexual abuse of children, the taking of motor vehicles without consent, corporate crime, foot-ball 'hooliganism', state terrorism, traffic offences, 'road rage', violence towards other men and so forth (each of the above has been the subject matter of recent analyses). ${ }^{6}$

In some contexts, masculine gender identity is associated with criminal propensity: "the more serious the type of offending, the higher the levels of masculinity". ${ }^{7}$ Even though cultural values can encourage violence, its internalization is not homogenous, but "for men in marginalized communities, where educational or occupational alternatives for achieving masculinity are difficult, violence can become an acceptable way of demonstrating manhood". ${ }^{5}$ In Mexico, some authors have studied the importance of aggression and violence as traits constitutive of hegemonic masculinity. ${ }^{8-13}$ For example, de Keijzer $^{12}$ thinks that independence, aggression, rivalry, and the embodiment of violent and reckless behaviors in a variety of acts (driving vehicles, abusing drugs, exerting violence and performing unprotected sex practices) can be identified as serious risk factors in Mexican society. Tunón \& Bobadill $^{8}$ assert that masculinity characteristics produce, through a complex construction process of stereotyping, a specific risk for the health and life of males. We can say, with Michael Kaufman, those men "internalize" violence; boys and men learn to selectively use violence and to redirect a range of emotions into rage. As long as violence assure on men privileges and forms of power, acts of violence make sense.

What Kaufman calls "the triad of men's violence" means that men's violence against women "does not occur in isolation but is linked to men's violence against other men and to the internalization of violence, that is, a man's violence against himself" Kaufman. ${ }^{14}$ If we examine these two kinds of violence-against other men and against oneself-we can explain phenomena as the fact that so many men-compared with women-die because of violent factors. The constitution of male identity involves "fear, isolation, anger, selfpunishment, self-hatred, and aggression" ${ }^{14}$ which, in the long term, are health issues in every society. In Table 1 we can see the difference between men's and women's violent deaths in Mexico. If we separate the figures of death caused by aggressions in age groups (Table 2), the difference is much more acute. (Note that the last row in Table 2 adds three age groups.) Then it is very important to understand the cultural mechanisms through which violence becomes a feature of masculinity. We can count, among other rituals, the celebration of men's violence in sport, cinema, literature and warfare, from where boys learn to repress their feelings of fear and pain through experiences of fighting. According to Kaufman, "On the sports field we teach boys to ignore pain. At home we tell boys not to cry and act like men. Some cultures celebrate a stoic manhood".

Table I Violent Deaths, Mexico, 20I I, men and women

\begin{tabular}{lllll}
\hline & Total & Men & Women & $\mathrm{m} / \mathbf{w}$ \\
\hline Total [all causes] & 590,693 & 332,646 & 257,468 & 1.29 \\
Accidents & 36,694 & 28,191 & 8,457 & 3.33 \\
traffic & 16,612 & 13,148 & 3,445 & 3.81 \\
Aggressions & 27,213 & 24,257 & 2,693 & 9 \\
Suicide & 5,718 & 4,621 & 1,095 & 4.22 \\
Total violent deaths & 69,625 & 57,069 & 12,245 & 4.66 \\
\hline
\end{tabular}

Source: INEGI. Estadísticas de mortalidad. 
Table 2 Deaths caused by aggressions, Mexico, 20I I

\begin{tabular}{lllll}
\hline Age group & Total & Men & Women & $\mathrm{m} / \mathbf{w}$ \\
\hline 15-24 years & 6,345 & 5,693 & 640 & 8.89 \\
$25-34$ years & 7,990 & 7,322 & 657 & 11.14 \\
$35-44$ years & 5,735 & 5,234 & 497 & 10.53 \\
$45-64$ years & 3,983 & 3,544 & 435 & 8.14 \\
15-44 years & 20,070 & 18,249 & 1,794 & 10.17 \\
\hline
\end{tabular}

Source: INEGI. Estadísticas de mortalidad.

\section{Methods}

This text is part of a larger research project entitled 'Discursive order and technologies of gender in boxing'. Field research was conducted in Mexico City from September 2005 to September 2008 with the aim to understand the phenomenon of female access to a hitherto exclusively male domain. In 1999, the ban on female participation in professional boxing was lifted in the Mexican capital as a result of a controversy started by a lawsuit submitted by boxer and lawyer Laura Serrano. Boxing is a highly codified social activity. Its practice depends, first and foremost, on the contacts one is able to establish in a relatively closed and exclusive group of 'initiates' who will in turn provide access to the places where a corpus of knowledgenamely body techniques, rituals, ceremonies, mores of conduct as well as organizational rules for dealing with internal and external issues-is imparted. Part of an old and apparently rigid tradition, this knowledge is transmitted from one body to another through an arduous training and a voluntary submission to a hierarchical system of authority. In my investigation, from the very outset, it became clear that in order to proceed to the conceptual reconstruction of the social field of boxing, a structural analysis was in order. It was then when I decided to interview two different types of informants: on the one hand, the 'protagonists'-i.e., the athletes, male and female, who were actively engaged in boxing in the modalities of training and competition-and, on the other, the 'specialists'-trainers, managers, seconds, promoters, sport medics, journalists and officers-who move around the practice of boxing and, to some extent, guide it.

Being a fundamentally bodily discipline, direct observation of the activities involved in the training routine of boxing is essential if one is to understand their implications in the construction of the body and gender. The great majority of the interviews were conducted in gyms and arenas where informants train. The main criterion for picking out these places was that they featured female athletes. Even though the two-category classification of informants (i.e., protagonists, specialists) is superimposed to that of gender, it is deeply pervaded by it: boxing in Mexico City remains a predominantly masculine social field and though women are allowed to participate, they constitute a tiny minority. In the absence of official data, it is impossible to establish a credible proportion, but one could venture to say that there is one female boxer by every hundred male boxers. We can infer this figure from the statement provided by Ricardo Contreras, president of the Mexican Federation of Amateur Boxing, in interview (28 November 2005). He informed us that men's boxing is practiced in 180 countries, while women's boxing in just 20, and that in each country males greatly outnumber females. He provided the following data: An estimate figure of people registered in organized boxing in Mexico is between three and four thousand, and if one adds trainers, physicians, arbiters, judges and boxers the number reaches ten thousand; however, we planned a first national championship with the idea of strengthening it [women's division], but we could not get more than three female boxers in each category. As for professional boxers, you will not find more than five women in the different categories right now.

\section{Discussions}

Boxing is indefensible. Not only is it the most explicitly violent of all disciplines in the sports spectrum, it also is the one with the highest health risks. This of course is a point for contention and one that has been passionately discussed in the boxing circles from the very time of boxing's inception as a recognized form of sport, sanctioned by international organizations. The debate remains steeply polarized and it is difficult to imagine that a consensus will ever be reached. A neutral position towards boxing is impossible to maintain. While some vindicate it as a sufficiently noble activity, fit to belong in the realm of legitimate sports, others condemn it to the point of proposing its outright disappearance from the face of the earth. For example, on 5 December 1984, the American Medical Association adopted a resolution to apply for the abolition of professional and amateur boxing..$^{15}$ According to Hauser, ${ }^{15}$ to understand boxing: You have to grasp the reality of smashed faces and pain, and understand how they can be part of something courageous, exciting, and beautiful [...]; boxing is beautiful-the purest sport in the world (quoting Mike Jones) [...]. It's a dark world that takes what's most savage in man and pushes it center stage against a backdrop of exploitation and pain. But beyond the spectacle of violent confrontation, boxing offers courage and beauty, loyalty and strength. ${ }^{15}$ This polarization exists not only between the two opposing sides, but also among some specialists who have passed from absolute affiliation to total repudiation, maybe as a result of their close proximity to the stories and vicissitudes that surround the practice. For instance, Hugh McIlvanney says: "My own attitude to the issue of whether any decent society should tolerate fistfighting has been profoundly, perhaps boringly ambivalent for years [...]. I must admit that as I get older my enthusiasm for the game is increasingly under siege from my misgivings". ${ }^{16}$

In her extraordinary exercise of literary reflection, Joyce Carol Oates summarizes the problem in a convincing way by highlighting the deeply paradoxical character of boxing: "boxing's very image is repulsive to many people because it cannot be assimilated into what we wish to know about civilized man [...] boxing's display of direct and unmitigated and seemingly natural aggression is too explicit to be tolerated". ${ }^{17}$ For this author, the arduous, prolonged, overwhelming period of preparation for the practice of sport has an underlying eagerness to control one's own body: "sport's systematic cultivation of pain in the interests of a project, a life-goal: the willed transposing of the sensation we know as pain (physical, psychological, emotional) into its polar opposite," so that, by an act of determination, pain is transfigured by its opposite: "pain now but control, and therefore triumph, later". ${ }^{17}$ The will to control, a decisive ingredient of masculinity in the West, can be read as one of the chief meanings of the discursive order on gender. The study of sports from a gender perspective allows for a critical analysis of this type of masculinity. Its recurring themes are the body and the risks associated to the interpretation of manhood as a category constantly under scrutiny and dependent on the positioning of the subject. According to Young and White, "Masculinity is one of the more significant risk factors associated with men's illness", ${ }^{18}$ inasmuch as it produces gendered behavior by which physical risk is naturalized, promoted and celebrated. It is significant for men to participate in "violent sport practices that at any moment may result in 
varying degrees of physical damage". ${ }^{18}$ It is possible to prove that men are socialized through potentially hurtful game forms and use "sport and athletic bodies as key sites for "masculinity verification'," with no regard for the fact that often the result of those practices is a severe damage to the integrity of the body. ${ }^{18}$ These general characteristics of sports are all the more evident in boxing, but have other fields of expression.

Sugden ${ }^{19}$ points out that, as they choose to climb onto the ring, "boxers risk two categories of injuries to the brain": the first category is a product of the 'killer punch', which "rotates the skull faster than the brain inside, causes one or more of the delicate bridging veins between the cranium and the brain to become detached and, sometimes, snaps the head back against the top of the back bone, leading to unconsciousness, paralysis and, in the worst cases, death". The second category of injuries is related to the cumulative effects of the large amount of strikes a boxer receives on the head throughout his career and which produce the syndrome known as 'punch drunk': From 9 to 25 percent of former professional boxers suffer this syndrome on some degree. Medical symptoms include ataxia (loss of muscle control), slowed movement, awkward gait, Parkinson's type syndrome (which Ali is said to have), memory loss and dementia. A British study published in 1973 examined the lives of fifteen former boxers. The grim details include anecdotes of violent behavior, an inability to remain employed, failed marriages, vagrant lifestyles and early death. With some of the boxers, visible decline had set in as early as their late twenties. ${ }^{20}$

Kath Woodward ${ }^{21}$ has observed that "the primacy of 'the body' in boxing has great impact and can be troubling, especially in relation to risk and danger". It is a human activity that consumes, like no other, "the very excellence it displays" ${ }^{17}$ because the physical damage is not an accident in the ring but the main purpose of boxing: to incapacitate or render the adversary unconscious. However or maybe as a logical consequence of the link between masculinity and risk, the majority of boxers are oblivious to pain: Almost without exception they state that they're more afraid of losing than of being hurt; that during a fight an opponent's punches are less damaging physically than psychologically [...]. "Getting hit hard," says Larry Holmes, "doesn't really hurt. It's more like someone taking your picture. You see a flash, and then suddenly everything is groggy; but you recover". ${ }^{15}$

As Kath Woodward ${ }^{21}$ puts it: the violence in a fight is not imaginary; it is the materialization of violence through the contending bodies "Boxing is about being hit rather more than it is about hitting, just as it is about feeling pain, if not devastating psychological paralysis, more than it is about winning". ${ }^{17}$ Oates and Hauser coincide in pointing at the profoundly 'anti-natural' condition of a boxer in the ring who would rather endure physical pain than not feel pain at all: "If one cannot hit, one can yet be hit, and know that one is still alive". ${ }^{17} \mathrm{~A}$ fighter never admits to being hurt by a well-aimed punch. He (or she) will remark upon a self-inflicted injury-broken hand, dislocated shoulder-or on an injury caused by an illegal blow-head butt, elbow gouge, fist to the groin-but never on an ill effect from a legal blow. The better the fighter, the less likely he is to admit injury [...]. The boxer's model is the Stoa: the stiff upper lip and iron jaw. Acknowledge that someone has hurt you, and you are admitting that he can hurt you again, moving you one step closer to defeat [...]. Good fighters learn how to conceal these reactions as well, knowing that to show hurt is to offer opportunity. ${ }^{20}$ Fighters learn to dominate the avoidance of pain"man's most fundamental instinct"-in order to strike their opponents; that is, they "learn to take punches by taking punches". ${ }^{15}$ The pain inflicted and endured in a fight is only a fraction of the pain to which a boxer is exposed every day when he (or she) submits to a training regime directed towards success. ${ }^{21}$ Some boxers become 'punchy' (that is, they develop the 'punch-drunk syndrome') as a result not of the punishment taken during official combats, but of the accumulated effect of the strikes received during sparring [...]; black eyes, bloated cheeks and puffy lips, a frequently bleeding nose, bruised hands and ribs are frequent when the gloves are worn regularly.2 Based on moral as well as health concerns, detractors of boxing argue that its practice is obviously inadvisable: it is the only sport aimed at causing injuries and, according to some studies, 87 percent of boxers suffer from some kind of irreversible brain damage. ${ }^{a}$ This undeniable risk is a recurrent theme in the bibliography on boxing. Sugden confirms that in boxing the main objective is the head: "Whereas in almost all other sports serious injuries are the result of unintentional actions (or willful actions outside the rules of the sport), in boxing it is argued that the better and more successful a fighter is, the more likely it is that he will seriously injure his opponents". ${ }^{19}$ Hauser has it perfectly clear that getting hit in the head is an integral part of the practice of boxing and that "getting hit in the head thousands of times in training and in fights can cause brain damage": ${ }^{15}$ blows with force exceeding one thousand pounds [...]. Cuts to the face and body heal. Brain tissue does not [...]. 'Boxers' encephalopathy' is the scientific term for what others call 'punch-drunk.' Early symptoms include unsteadiness of gait, slight memory loss, and mental confusion. ${ }^{15}$ Anasi explores the meaning of expressions used in the language of boxing: "I'm going to bash your brains in ... ring your bell.....crack your skull....smash your face... split your wig....knock your block off." In the material world, "punches are inevitably directed at the head. In boxing, this inclination is known as head-hunting". 20 "Gloves are worn to protect the fists, not the brain. [Boxing is] the most violent activity condoned by man except for certain phases of law enforcement and war". ${ }^{15}$ Work at the gym and the repeated exercise of sparring develop a technique that has little to do with a 'natural' combat: In a street fight, a punch to the head generally breaks the hand of the person who throws it (it's said that the average street fight is over in five seconds, the loser going to the doctor with a fractured nose and the winner going to the doctor with a fractured hand). Skulls are harder than hands. In the bareknuckled era, fighters made substantial efforts to protect their hands, soaking them in brine and following special 'bone-hardening' diets. In bouts, bare-knuckle fighters had to be circumspect about the velocity and force of their punches, knowing that a blow struck too hard would result in fractured metacarpals and a lost battle. ${ }^{20}$ Hauser maintains that although they are usually not severe, blows received regularly during training sessions end up being more damaging than a knockout. Hargreaves ${ }^{23}$ adds that the most common occupational risk in male professional practice is the "punch-drunk syndrome': "a debilitating neurological disease which has features in common with Alzheimer's dementia and Parkinson's disease." Other common injuries include damage to the eyes and "the results of recent examinations of male amateur boxers show that there is a cumulative build-up of brain damage over time which goes undetected if untested". ${ }^{23}$ Anasi $^{20}$ maintains that a head shot "is something boxers learn to endure, even enjoy." According to his calculations, in a training period of nine months, the average boxer receives a little more than 130 severe blows in the head, plus dozens of other minor blows: most boxing injuries take place during sparring. In the gym, mismatches are common [...]. It remains a mystery to doctors why boxers, who regularly endure concussions, are not more affected by them. Part of the answer lies in the fact that boxers adopt behavior to buffer themselves from the most severe concussive effects. They learn to 'roll with the punches' $[\ldots]$ just get used to walking around dazed and irritable and unable to focus. ${ }^{20}$

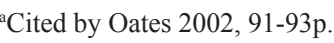




\section{Injury in high-risk sports activities}

However, in terms of pure and measurable health and life risks, boxing occupies an honorable sixth place after football, auto racing, hang gliding, mountaineering and hockey on ice. ${ }^{\mathrm{b}}$ Every day there is more information on the casualties resulting from sports, which constitutes a challenge to the assumption that the practice of sports guarantees good health and wellbeing: A survey of hospital emergency rooms and medical clinics in 1997 found a staggering number of sports injuries among U.S. children fourteen years old and under, led by bicycling (901,716 injuries), basketball $(574,434)$, football $(448,244)$, baseball $(252,665)$, and soccer $(227,157)$. In Canada, injuries-a substantial proportion of which are head, neck, and cervical spinal injuries-among children ice hockey players are also escalating. ${ }^{24}$ Notwithstanding this, it is known that not all sports accidents end up in the emergency room: "Injuries and pain levels that in other contexts would result in emergency-room visits, home bed rest, and time off work or school are considered a normal part of the workday for many athletes". ${ }^{24}$ For Messner, high performance athletes, "who are often portrayed as the epitome of good physical conditioning and health," have high probabilities of suffering "from a very high incidence of permanent injuries, disabilities, alcoholism, drug abuse, obesity, and heart problems": ${ }^{24}$ The instrumental rationality which teaches athletes to view their own bodies as machines and weapons with which to annihilate an objectified opponent, ultimately results in violence against one's own body. In fact, a former professional football player in the U.S. has an average life-expectancy of about 56 years (roughly fifteen years shorter than the overall average lifeexpectancy of U.S. males). ${ }^{25}$ As I have argued earlier, the dangers incurred when engaging in certain practices and the forgetfulness towards one's own body-which can either be interpreted as an illusion of invulnerability, contempt for the physical content of self-care, or outright negligence-have a strong gender content. Men and women seem to have a different attitude towards pain and risk, since "there are numerous ways that men, more than women, take risks, endure pain, and suffer ill health through sport and play". ${ }^{18}$ In the USA, males represent $62.5 \%$ of deaths in winter sports, $89.5 \%$ in aquatic sports and $91.5 \%$ in motorized sports. Moreover, males tend to incur more severe lesions than women. "For respondents over the age of 10, boys were more likely than girls to have been treated for a bone fracture, a cut or laceration, a concussion, or an abrasion" ${ }^{18}$ Statistics on sports-related morbidity show that males are more exposed to injuries, thanks to the fact that "social processes producing dominant forms of masculinity and popular sports practices interact to systematically produce injury, disability, and even death". ${ }^{18}$ However, gender alone is not a reliable indicator when trying to predict the incidence of injury in high-risk sports activities since, though still a minority, every day more women take part in such practices.

\section{Boxers in Mexico}

Boxing is therefore placed within a culture of the body whose repercussions go well beyond the realm of sports. Contradictory though it may seem, one of the recurrent arguments in favor of boxing is the aforementioned 'honorable sixth place' among the most dangerous sports activities. Interviewees for this study often stressed the banality of questioning the risks in boxing when compared to 'more dangerous' sports: Ricardo Contreras: There are more casualties in horse races, in auto races, in football, and the lesions are much more severe than those in our sport. The difference is, you know, that when

\footnotetext{
b"Since [...] 1884, according to official records approximately 500 people have died in the ring worldwide. However, in terms of fatalities, boxing is a relatively safe sport". ${ }^{19}$
}

an auto race pilot dies, the accident won't hit the front pages unless the deceased is a world champion; but in boxing, when a fighter dies, the media will make a big fuss because of its brutality and all, but there are sports that rank much higher than ours in terms of the risk of severe injury (28 November 2005, President of the Mexican Federation of Amateur Boxing). Although this justification does not in any way deny the intrinsic dangerousness of boxing-more to the contrary, it vindicates it as one of its most important characteristics, for without risk daring could not be exhibited, and in the field of boxing, daring is a constitutive element of masculinity-the discourse is an intricate one and its degree of conclusiveness depends on the informant's place in a rigidly structured hierarchy responding to factors such as age, occupation and authority.

Benjamín Ibáñez Ureña: There was a problem when they said "no children," and once Doctor Horacio himself [Horacio Ramírez, physician at the Federal District's Boxing Commission] said: "no children, I won't authorize it." And I told him: "excuse me, Doctor, but here I am the one who authorizes, so if you want to give them... to carry out their checkup do it, otherwise I will ask any of the four or five doctors from the Institute of Sport who'll come along with us." And then he goes: "Children tend to hit each other," and I go: "No, they don't hit, they barely slap each other, and we will take all possible precautions." We have always invited Doctor [Esteban] Martos and he always supports us fine. Now he's teaching a course because it's important that we all learn how to handle our boys. Whenever we can't, we send them to him and he very kindly takes them free of charge and always goes: "Send them to me, as many as you like" (5 May 2006, Vice-president of the Federal District's Amateur Boxing Association).

The complexity of the debate is increased by a need to reaffirm, on the one hand, boxing's extreme dangerousness-on which its merit as a male activity depends-and, on the other, to vindicate it as a safe and healthy practice. Informants situated at high levels of the field (association directors, sports physicians, civil servants) often make this rhetoric summersault from the margins: they no longer practice boxing and their position of authority derives, in some cases, from their former experience as fighters, but above all from a bureaucratic appointment or from the medical profession. ${ }^{\mathrm{c}}$ Their opinions reveal the difficulty to make sense from a practice in which, in the words of Wacquant, "the body is at the same time weapon, bullet and target". ${ }^{22}$

A very common strategy is the denial of risk. In this discursive maneuver dangerousness is attributed to factors considered 'external' to the practice: boxing is not dangerous in itself; the problem lies in the poor observance of even the minimum standards of care and discipline that guarantee the security of the athletes. According to some of our informants, if on the one hand, boys are well trained and familiarized with the boxing techniques, if they do not commit excesses outside the gym (lack of sleep, alcoholism, overeating) and respect the directions of their managers and, on the other hand, if there is good medical vigilance and a rigorous supervision to ensure even matches, risks are minimized. Roberto Santos: People are right when they say it is very dangerous, that there are casualties in fights, but the truth is deaths in boxing happen for other reasons: Because fights are uneven, because one of the fighters weighs four or five kilograms more than the other, or because the boxer was not well prepared; for it is common to hire boxers with only a week in advance and with no training and to tell them: "take it or leave it, there will be no other world-class chance

\footnotetext{
cAlthough the majority of sports officers and administrators were athletes in their youth, and the boxing field is dominated by ex-fighters, we found several specialists that had never got onto the ring.
} 
for you." What are they expected to do? They take it! Responsibility is thus shifted from the organizations in charge of overseeing every athlete's behavior to the greedy accompaniment of managers, and exceptional cases become the norm, which poses a heavy burden on the most needy. According to this interpretation, many of boxing's problems derive from the bad reputation the misbehavior of fighters from the lowest ranks of society has earned it. The following passage from Ricardo Garibay's ${ }^{26}$ book on Rubén Olivares (a.k.a. "El Púas") summarizes this perception: Mantequilla [José Mantequilla Nápoles] has made more than twenty million pesos and has not even one cent left. It's the horse races and the betting. On one of the last occasions he was here he made more than ninety thousand dollars clean, and after one week, as I was chatting with Cuco Conde-his manager, as you know-suddenly someone comes and tells him: "Mantecas wants you to send him ten thousand pesos urgently." "Good heavens! But if just four days ago he had one million pesos; I myself deposited them on his account!" "Well, he says now!" Give me a break! I love the guys. It hurts me to see them losing a fight; it hurts me to see them be beaten more than necessary; it hurts me to see them end up in misery. But who could control them? Rubén [Olivares] has made more than fifteen million pesos and look at him, fighting for ten thousand dollars which won't last him fifteen days. There's no way they will change. Money just gives them more and more and more of the same they have had all along: shit. And soon they are finished off, with not much to give anymore. ${ }^{26}$ Nevertheless; there is a sharp awareness of the role the organizing structure must play in the protection of the health and well being of the participants. The medical expert's eye and a strict observance of the rules of fair competition are elementary to the staging of a fight: Rafael Ornelas: As a health professional, I can guarantee that the most difficult fights are those engaged outside the ring and not in it; and that when a fighter is well prepared, when he has observed some kind of strict diet and trained in the biomechanics of movement, and his work load has been properly administered, injuries are unlikely to originate in the ring. The decline of some fighters is a result of their extravagant ways, the company they seek, the... and here we go again-their social background, their bad behavioral habits and the fact that when they come to see themselves as idols they often forget to hold something back for their own sake; and it is then when injuries begin to appear. True, the sport is not free from direct contact with the brain and cerebellum, but if you look closely you will see fighters who are extraordinarily articulate and who have never lost a combat, like Ricardo "Finito" López; and others like Raúl "Ratón" Macías, who escaped poverty thanks to boxing, and Óscar de la Hoya who's a millionaire, as is Sugar Ray Leonard... Yes, there are also cases we can consider as the other side of the coin-like Mike Tyson, to cite but an example, and whose behavior is, well... far from good, and other boxers whose life has been adversely affected by their practicebut I insist, these cases are more a consequence of the kind of life they lead than of the risks involved in the sport (12 June 2006, physician at the Mexican Olympic Committee). A less optimistic perspective is to be found among those informants at the intermediary levels (trainers, managers)

Ignacio Beristáin: In Indonesia, eight fighters have died in one year It is horrible. The authorities in charge of boxing worldwide-there are several organizations-cannot agree on the real causes of what is happening. Generally speaking, it's disturbing that sometimes those authorities $[\ldots]$ because fights are totally uneven. All over the world fighters have different levels-some are more technical, others stronger, others have a stronger punch-but there are some who don't even have a record. There was a fight between a Mexican and a North American and the North American was taller and apparently a better boxer in terms of his style, his technique-more refined-but he was unable to dodge a blow, all blows coming from the Mexican he would get right in the head and he was very strong, with good resistance, but I say even a rock will eventually crack if it gets knocked once and again, so the Mexican continued knocking the North American in the head, who died two or three days later because he had no idea of how to dodge a blow. He got, as the common saying goes, "even the unintended blows." I think there ought to be a special commission somewhere which said "hey, before authorizing a program let's analyze it carefully, even if that takes more time; this fight can be dangerous for this reason, for its characteristics," for example, the bandaging [...] which is made of gauze and adhesive tape, and sometimes the blows are stronger as a result and hurt more... and well, the head of a human being is not meant to receive blows, neither are the hands. There are fractures, of fists, of jaws, lesions that never totally heal. This is why I say [...] I should defend my work, but I can't stop thinking that it is dangerous (5 October 2005, trainer). For boxers, who find themselves at the center of discussion and who are the ones who embody it, the issue has a painful actuality. However, deep in their discourse one can find a need to 'make sense', to overcome the unreasonable act of practicing boxing by legitimizing it at the very crux of their subjective construction.

David Sánchez Sánchez: As a sport, boxing is very good for our health and at the same time it's also a little dangerous; the risk is high [...] I mean, I say when one has an appointment, so... one has to go there, but unfortunately it was my brother's turn and many people want me to retire, but it would be an act of cowardice, if I go, because he fought to the end and if I go like that, it's not... my dignity doesn't allow me (29 September 2005, boxer).

\section{Conclusions}

Through the transmission of a tradition consisting of a corpus of rules, body techniques, rituals and norms of conduct, the social field of boxing reproduces the imaginary of masculinity in one of its more crude versions: that which equates virility with brute force, enacted as a direct physical attack leading to the destruction of one's own body and the body of the adversary. I have tried here to expound and reflect upon the contrasting strategic discourses of those who defend the practice of boxing and those who question its position as an established sport internationally. In so doing I have drawn from both the existing literature on the paradoxes of boxing in relation to violence and health, and the testimonies obtained directly from different actors of the boxing scene in Mexico City. At a deeper level, these strategies reveal a close identification between masculinity and the physical effort involved in a competition arena to destroy the excellence achieved through a long and strenuous training process; where pain is transposed with control, and the expression of virility becomes a true risk factor. This kind of control by which the body is simultaneously regarded as a weapon, a bullet and a target is translated, in the words of boxers, trainers and specialists of boxing, into one of the elements that allow for the identification of gender today not as an essence of identity, but rather as an action which is enacted and actualized in each circumstance and social field.

\section{Funding details}

No funding.

\section{Acknowledgments}

None. 


\section{Conflicts of interest}

The author declares that there are no conflicts of interest.

\section{References}

1. Burcar, Veronika. Doing masculinity in narratives about reporting violent crime: young male victims talk about contacting and encountering the police. Journal of Youth Studies. 2013;16(2):172-190.

2. Barnes Collin D, Ryan P Brown, Michael Tamborski Y. Living Dangerously: Culture of Honor, Risk-Taking, and the Nonrandomness of 'Accidental' Deaths. Social Psychological and Personality Science. 2012;3(1):100-107.

3. Whitehead Stephen M, Frank J Barrett. The Masculinities Reader. Cambridge: Polity Press; 2001. 400 p.

4. Carrigan Tim, Bob Connell y John Lee. Toward a New Sociology of Masculinity. Theory and Society. 1985;14(5):551-604.

5. Crowther Simon, Christina Goodson, James McGuire y, et al. Dickson, Having to Fight. Journal of Interpersonal Violence. 2013;28(1):62-79.

6. Collier Richard, Lode Walgrave. Masculinities and crime. Criminal Justice Matters. 1998;34(1):21-24.

7. Beesley Francis, James McGuire. Gender-role identity and hypermasculinity in violent offending. Psychology, Crime \& Law. 2009; 15(2-3):251-268

8. Tuñón Pablos Esperanza, Daniel Jacob Bobadilla Bernal. Mortalidad en varones jóvenes de México. Estudios Sociales. 2005;13(26):68-84.

9. Núñez Noriega, Guillermo. Masculinidad e intimidad: identidad, sexualidad y sida. México: PUEG-UNAM /COLSON/Porrúa; 2007a. 7 $\mathrm{p}$

10. Núñez Noriega, Guillermo. La producción de conocimientos sobre los hombres como sujetos genéricos: reflexiones epistemológicas. Ana Amuchastegui, Ivonne Szasz, coordinadoras. México: El Colegio de México; 2007b. 18 p.

11. Rivas Sánchez Héctor Eloy. ¿El varón como factor de riesgo? Masculinidad y mortalidad por accidentes y otras causas violentas en la sierra de Sonora. Estudios Sociales. 2005;13(26):28-65.

12. Keijzer Benno de. El varón como factor de riesgo: masculinidad, salud mental y salud reproductiva. In: Esperanza Tuñón, editor. Género y Salud en el Sureste de México. México: ECOSUR/UJAT; 1997.15 p.
13. Figueroa Perea, Juan Guillermo, Paternidad. ¿es posible combinar estos términos? In Estudios sobre Varones y Masculinidades para la generación de políticas públicas y acciones transformadoras. Mujer y Salud en Uruguay (MYSU)/ Espacio Salud; 2011. 251 p.

14. Kaufman Michael. The Seven P's of Men's Violence. 2001.

15. Hauser, Thomas. The Black Lights/Inside the World of Professional Boxing. Fayetteville: The University of Arkansas Press, 2000. 259 p.

16. McIlvanney Hugh. The Hardest Game. New York: Contemporary Books; 2002. $336 \mathrm{p}$.

17. Oates, Joyce Carol. On boxing (expanded edition with photographs by John Ranard). New York: ECCO (Harper Collins); 2002. 205 p.

18. Young Kevin, Philip White. Researching Sports Injury/Reconstructing Dangerous Masculinities. In: Jim McKay, Michael A Messner, editors. Masculinities, Gender Relations and Sport. London: Sage Publications Inc; $2000.210 \mathrm{p}$.

19. Sugden John. Boxing and Society/An International Analysis. New York: Manchester University Press; 1996. 218 p.

20. Anasi Robert. The Gloves/A Boxing Chronicle. New York: North Point Press; 2002. 320 p

21. Woodward Kath. Boxing, Masculinity and Identity/The 'I' of the Tiger New York: Routledge; 2007. 177 p.

22. Wacquant Loïc. Entre las cuerdas/Cuadernos de un aprendiz de boxeador. Madrid: Alianza-Ensayo; 2004. 254 p.

23. Hargreaves Jennifer. Women's Boxing and Related Activities: Introducing Images and Meanings. Body and Society. 1997;3(4):33-49.

24. Messner Michael A. Taking the field/Women, Men and Sports. Minneapolis: University of Minnesota Press; 2002. 268 p.

25. Messner Michael A. When Bodies are Weapons: Masculinity and Violence in Sport. International Review for the Sociology of Sport. 19990;25(3):203-220.

26. Garibay Ricardo. Works collected (chronicle one). Mexico: Ocean/ Conaculta; 2001. 247 p. 